\title{
Improved Discharge Performance of Mg-6Al-7Pb Alloy by Microalloying with Ce
}

\author{
Yiping Wu ${ }^{1}$, Zhifeng Wang $^{2}$, Yu Liu ${ }^{l}$, Guofeng $\mathrm{Li}^{1}$, Shaohui Xie ${ }^{1}$, Hui Y ${ }^{2}$, Hanqing Xiong ${ }^{1,2, *}$ \\ ${ }^{1}$ Department of Mechanical and Electronic Engineering, Changsha University, Changsha, 410083, \\ China \\ ${ }^{2}$ School of Materials Science and Engineering, Hebei University of Technology, Tianjin, 300130, \\ China \\ *E-mail: xhanqing@163.com
}

doi: $10.20964 / 2018.11 .06$

Received: 8 June 2018 / Accepted: 20 July 2018 / Published: 1 October 2018

\begin{abstract}
$\mathrm{Mg}-6 \mathrm{Al}-7 \mathrm{~Pb}$ (wt.\%) alloys with different Ce contents are prepared and their electrochemical discharge performances are measured in this research. Under casting condition, $\mathrm{Mg}-6 \mathrm{Al}-7 \mathrm{~Pb}-0.3 \mathrm{Ce}$ alloy shows better electrochemical activity than other alloys. Subsequently, the discharge property of $\mathrm{Mg}-6 \mathrm{Al}-7 \mathrm{~Pb}-$ $0.3 \mathrm{Ce}$ alloy is further enhanced by multi-pass hot rolling. The result is verified by electrochemical tests and morphology observation. $\mathrm{Mg}_{2} \mathrm{~Pb}$ and $\mathrm{Al}_{4} \mathrm{Ce}$ phases are observed, and fine grains are obtained in as-rolled $\mathrm{Mg}-6 \mathrm{Al}-7 \mathrm{~Pb}-0.3 \mathrm{Ce}$ alloy. For as-rolled $\mathrm{Mg}-6 \mathrm{Al}-7 \mathrm{~Pb}-0.3 \mathrm{Ce}$ alloy, the increased discharge performance is attributed to the synergistic effect of the dispersive $\mathrm{Al}_{4} \mathrm{Ce}$ and $\mathrm{Mg}_{2} \mathrm{~Pb}$ phases. The $\mathrm{Mg}$ air battery based on as-rolled $\mathrm{Mg}-6 \mathrm{Al}-7 \mathrm{~Pb}-0.3 \mathrm{Ce}$ alloy supplies higher peak power density (102.7 $\mathrm{mW} \cdot \mathrm{cm}^{-2}$ ) than that based on as-rolled $\mathrm{Mg}-6 \mathrm{Al}-7 \mathrm{~Pb}$ anode. Therefore, the as-rolled $\mathrm{Mg}-6 \mathrm{Al}-7 \mathrm{~Pb}-$ $0.3 \mathrm{Ce}$ alloy is an excellent anode material for Mg-air battery.
\end{abstract}

Keywords: Magnesium anode; Microalloying; Hot rolling; Microstructure; Discharge performance

\section{FULL TEXT}

(C) 2018 The Authors. Published by ESG (www.electrochemsci.org). This article is an open access article distributed under the terms and conditions of the Creative Commons Attribution license (http://creativecommons.org/licenses/by/4.0/). 